\title{
Effects of Retail Employees' Behaviours on Customers' Service Evaluation
}

\author{
CHANAKA JAYAWARDHENA ${ }^{*, 1}$ and ANDREW M. FARRELL ${ }^{2}$
}

\author{
* Corresponding Author: \\ ${ }^{1}$ Senior Lecturer in Marketing \\ School of Business and Economics \\ LE11 3TU, United Kingdom \\ Tel: +44 (0)150922 8831 \\ Email: C.Jayawardhena@Lboro.ac.uk
}

\author{
${ }^{2}$ Lecturer in Marketing \\ Aston Business School \\ Aston University \\ Aston Triangle, \\ Birmingham, B4 7ET. \\ Tel: +:+44(0)1212044874 \\ Email: a.m.farrell2@aston.ac.uk
}




\title{
Effects of Retail Employees' Behaviours on Customers' Service Evaluation
}

\begin{abstract}
Purpose - The purpose of this paper is to test a conceptual model of the effects of customer and service orientation behaviours of individual retail employees on individual customers' perceptions of service encounter quality, service quality, value, satisfaction, and behavioural intentions.

Design/methodology/approach - The sample $(n=271)$ was customers of a supermarket in Central India, and they completed questionnaires following mall intercept. To test the hypotheses, structural equation modelling using LISREL 8.7 was employed.

Findings - 1) service and customer orientation behaviours are positively related to service encounter quality and service quality, 2) service encounter quality is positively related to service quality and customer satisfaction; 3 ) service quality is positively related to value perceptions and customer satisfaction; and 4) customer satisfaction is positively related to retail customers' behavioural intentions. However, value is not related to customer satisfaction.

Research limitations/implications - More research is needed on customer perceptions of value in non-Western contexts and service evaluation frameworks in other cross-cultural contexts Practical implications - Retail managers need to train or select retail personnel that are able to perform their roles in a service oriented and customer oriented way, and value does not appear to be as important to Indian retail customers as it is to Western retail customers.

Originality/value - This study extends current service evaluation frameworks by including service orientation and customer orientation as antecedents, and it analyses an Indian retail context.

Keywords - India, Retail, Customer orientation, Service orientation, Service evaluation

Paper type - Research paper
\end{abstract}




\section{INTRODUCTION}

While some retail consumption may take place at a group level, the majority of retail consumption episodes are individual in nature. Most retail service consumption episodes are characterised by an individual consumer interacting with individual employees. Research indicates that an appreciation of how retail consumers evaluate the service they receive can be highly useful in understanding customer loyalty (Gupta and Zeithaml, 2006). Indeed, there is a long standing tradition of research examining how individual retail customers evaluate the services they consume. This research has identified a cluster of variables contributing to retail customers' service evaluations (Cronin et al., 2000; Brady et al., 2005; Maxham et al., 2008). Furthermore, certain variables consistently feature: perceived service quality, perceived value, customer satisfaction, and behavioural intentions.

However, while research examining retail customers' service evaluation is evolving, investigation of the antecedent role that retail employees play in the overall service evaluation process is less developed (Brady and Cronin, 2001; Hennig-Thurau, 2004). Given that employees have an important role in the formulation of retail customers' service evaluations (Bitner, 1990), it is worthwhile to investigate the impact of employee inputs into this process. With this in mind, recent work has highlighted two particular constructs of interest: customer orientation (CO) (Brown et al., 2002) and service orientation (SO) (Homburg et al., 2002). These variables are hypothesised to play an important role in determining the quality of retail customers' service evaluations (Brady and Cronin, 2001). However, research has yet to assess the combined role of both of these employee-specific factors. Furthermore, the mechanisms by which these two individual employee orientations may influence service evaluations have only been tentatively explored (see, e.g., Brady and Cronin, 2001).

This research seeks to rectify this gap, by developing and testing a comprehensive model of customers' service evaluation in a retail context, with additional investigation of the antecedent role that customer orientation and service orientation play. As such, this study seeks to evaluate the relationships between the following variables: customer orientation, service orientation, perceived service encounter quality, perceived service quality, perceived value, customer satisfaction and 
customers' behavioural intentions. To the authors' best knowledge, this represents the first study to simultaneously examine these constructs as an extended model of service evaluation.

In addition to the first objective, whilst the volume of retailing research is considerable, the majority of work has concentrated on developed market economies (Brady et al., 2005). Countries such as India, Russia and China (PRC) provide unprecedented opportunities to investigate whether Western models of retail service evaluation are transferable to non-Western contexts. Therefore, the study's second objective is to situate the research within the context of one such developing economy, India, because it represents a significantly different cultural market to that offered by the West (c.f., Hofstede, 1980).

To summarise, this paper has two major objectives: one, to examine the antecedent role of customer orientation and service orientation in the retail service evaluation process; and second, to examine the nature of the service evaluation process in a developing economy, India. The remainder of this paper is structured as follows. The following section will provide background information on the constructs under examination. In this section we will formulate hypotheses and present a conceptual model. The research methodology will then be detailed. Section three presents the analysis and results. Finally, the paper will conclude with discussion of study outcomes and their implications for academics and practitioners, limitations of the study, and future research directions.

\section{CONCEPTUAL FRAMEWORK}

\section{Retail Service Evaluation}

Retail Service evaluation models, or more general service evaluation models have gained prominence as researchers build a more comprehensive understanding of the process customers go through when evaluating service delivery. A number of variables feature prominently: perceived service quality, perceived value, customer satisfaction, and behavioural intentions (Cronin et al., 2000; Maxham et al., 
2008). Service quality is how well a delivered service matches customers' expectations of that service (Parasuraman et al., 1988). Perceived value, based on equity theory, refers to customers' assessment of what is right, fair or deserved given the cost of an offering (Bolton and Drew 1991). Buyers' perceptions of value consider the trade-off between the product qualities and the sacrifice they make in monetary terms (Cronin et al., 2000). Satisfaction reflects whether a consumer believes that the possession and/or use of a service evokes positive feelings (Rust and Oliver, 1994). Behavioural intentions are indicators of whether a customer will remain with or defect from an organisation (Zeithaml et al., 1996).

When formulating service evaluation models, many researchers rely on attitude theory. One of the goals of attitude theory is to determine how attitudes drive intentions. Among the numerous schools of thought on attitudes, the theory of reasoned action (Ajzen and Fishbein, 1980) is perhaps the most prominent. The theory of reasoned action postulates that intentions are the direct outcome of attitudes, subjective norms and beliefs. We therefore specify satisfaction as a central mediating variable between the effects of service quality, service encounter quality and value and customers' behavioural intentions. The rationale for this model is that since satisfaction is an affective variable whereas quality and value are cognitive evaluations (Oliver, 1997), a direct link to intentions is justified by models that specify a cognition-affect causal ordering (e.g., Bagozzi, 1992). In effect, satisfaction is an affective-oriented mediator resulting from quality and value evaluations. Value is included in our model because its presence increases service evaluation models' ability to explain variance in customers' behavioural intentions (Cronin et al., 1997). We now present the formulation of our service evaluation model.

\section{Service Quality}

Service Quality is an influential determinant of perceived value (Andreassen and Lindestad, 1998). According to Hellier et al. (2003), perceived value is positively influenced by perceived quality. Several scholars have reported that customers' evaluation of perceived service value depends directly 
on customers' evaluation of perceived service quality (e.g. Andreassen and Lindestad, 1998). Furthermore, Sweeney et al. (1999) have claimed that perceived quality is a pivotal determinant of perceived value. In light of this, we hypothesise that:

$H_{1}$ : Perceived service quality is positively related to perceived value.

\section{Customer Satisfaction}

Due to its influence on consumers' behavioural intentions and customer retention (Bolton and Drew, 1991; Dholakia and Zhao, 2010), customer satisfaction has been the subject of much attention (e.g. Cronin et al., 2000; Oliver, 1997). A direct positive relationship between perceived value and customer satisfaction has been indicated by a variety of studies (Fornell et al., 1996). The presence of value in service evaluation models increases researchers' ability to explain variance in customers' behavioural intentions (Cronin et al., 1997). Customer satisfaction is a consequence of perceived value (Hallowell, 1996). Fornell et al. (1996) highlight the importance of the relationship between customer satisfaction and perceived value. In their study, three antecedents of customer satisfaction are identified: perceived value, perceived quality and customer expectations. They go on to emphasise that "the first determinant of overall customer satisfaction is perceived quality [...] the second determinant of overall customer satisfaction is perceived value" (Fornell et al., 1996, p. 96). Value disconfirmation literature also supports the relationship between customers' perceived value and customer satisfaction (Hellier et al., 2003). Perceived value can be considered pre or post purchase (Eggert and Ulaga, 2002) as a customer seeks additional benefit in comparison to the cost when purchasing a product or service. If the product is unaffordable and perceived quality is inferior, the customer may not want to buy that product - this is a case of pre purchase perceived value. Alternatively, customer satisfaction can be a post purchase phenomenon (Eggert and Ulaga, 2002) because the perceived value of a product or service is evaluated following customers' experiences with the product or service. Given the above discussion, we hypothesise: 


\section{$\mathrm{H}_{2}$ Perceived value is positively related to customer satisfaction.}

There is little agreement over the relationship between perceived quality and customer satisfaction. Some service evaluations models (e.g., Bitner, 1990) specify satisfaction as an antecedent to service quality based on the premise that service quality is a general evaluation similar to an attitude, and is super ordinate to satisfaction. For example, Bolton and Drew (1991) advocate that customer satisfaction is affected by disconfirmation, expectation and actual performance and customer satisfaction, in turn, becomes an input to customers' perceptions of service quality. However, other service evaluation models (e.g., Anderson and Fornell, 1994) adopt the appraisal-response-coping sequence (Lazarus, 1991) or the cognitive-emotive causal order (Oliver, 1997), which positions satisfaction as super ordinate to service quality. Parasuraman et al. (1988) argue service quality is a global judgment or attitude of the superiority of the service, whereas customer satisfaction is transaction-specific. Fornell et al. (1996) found that overall quality, price and expectations affected customer satisfaction and claimed that customer satisfaction depended on the anticipated quality of future service. To unify these diverging views, Cronin and Taylor (1992) tested both causal orderings of satisfaction and service quality (i.e., service quality $\rightarrow$ satisfaction and satisfaction $\rightarrow$ service quality) and determined that service quality is an antecedent of customer satisfaction, reinforcing earlier work (e.g. Andreassen and Lindestad, 1998). On balance, we postulate:

\section{$H_{3}:$ Perceived service quality is positively related to customer satisfaction.}

\section{Behavioural Intentions}

The theory of reasoned action (Ajzen and Fishbein, 1980) suggests that intentions are the direct outcome of attitudes (and subjective norms). More recent work in attitude theory (e.g., Bagozzi, 1992) challenges this perspective arguing that attitude theories "trade specificity for parsimony" (Bagozzi, 1992, p. 201). Hence, researchers have formulated more complex models of service evaluation (e.g., Brady et al., 2005). We follow a similar approach, with numerous antecedents to behavioural 
intentions. However, since satisfaction is an affective variable and quality and value are cognitive evaluations (Oliver, 1997) only satisfaction is positioned directly antecedent to behavioural intentions, as per the theory or reasoned action (Ajzen and Fishbein, 1980). Satisfaction linking directly to behavioural intentions is justified by theoretical models that specify a cognition-affect causal ordering (e.g., Bagozzi, 1992). That is, satisfaction is positioned as an affective-oriented mediator that follows from quality and value evaluations. We therefore propose:

\section{$H_{4}:$ Customer satisfaction is positively related to behavioural intentions.}

\section{Service Encounter Quality}

Shostack's (1985) definition of service encounters encompasses variables beyond the interpersonal perspective, including physical surroundings and self-service technology. Alternatively, narrow definitions of service encounters also exist, focusing on the interpersonal nature of the encounter. For instance, Surprenant and Solomon (1987) define the service encounter as a dyadic interaction between the customer and service provider, suggesting that service encounters are role performances (Czepiel et al., 1985). During the service encounter, or 'moment-of-truth', the formation of customer perceptions is based more upon the emotional and intangible content of the encounter than on surroundings (Lemmink and Mattsson, 2002). Here, Surprenant and Solomon's (1987) dyadic conceptualisation of service encounters is adopted.

As explained by Farrell et al. (2001, p. 577), "service quality represents a customer's assessment of the overall level of service offered by an organisation, and this assessment is often based upon perceptions formulated during service encounters." Czepiel et al. (1985) also place the service encounter at the heart of customers' perceptions of service quality. So, positive perceptions of service encounter quality should lead to normative expectations of the overall quality of the service. Service quality is a holistic judgment of quality, and the quality of individual service encounters should contribute towards this judgment. Thus, we expect that: 
$H_{5}$ : Perceived service encounter quality is positively related to perceived service quality.

In light of the discussion regarding Hypothesis 3 (i.e., that satisfaction is an outcome of service quality) we argue that service encounter quality will be related to satisfaction. Indeed, "the satisfaction process often has a strong social dimension" (Fournier and Mick, 1999, p. 15, emphasis in the original), so it should be related to the quality of the interaction between service provider and customer. We therefore anticipate the following:

$H_{6}:$ Perceived service encounter quality is positively related to customer satisfaction.

\section{Extending the Retail Service Evaluation Model}

In expanding service evaluation models, a natural starting point is the role that service employees play (Brady and Cronin, 2001; Susskind et al., 2003). Because of this, the service employee-related constructs of customer orientation and service orientation are included. Customer orientation and service orientation were chosen as they have been the focus of recent research (Brown et al., 2002; Homburg et al., 2002). We position customer orientation and service orientation as antecedents to our extended model of service evaluation. Furthermore, whilst customer orientation tends to focus upon both philosophical and behavioural elements of service delivery (Saxe and Weitz, 1982), service orientation in our study deals specifically with behavioural-only performance.

\section{Customer Orientation}

Despite the amount of customer orientation research (Brown et al., 2002; Donavan et al., 2004; Knight et al., 2007; Saxe and Weitz, 1982), the question of how customer orientation influences perceived organisational performance from the customers' perspective is under researched (Brady and Cronin, 2001; Hennig-Thurau, 2004). Customer orientation is viewed as a desire by an employee to help 
customers meet their needs during the performance of organisational tasks (Brown et al., 2002). Our hypothesis concerning the influence of customer orientation is threefold. Firstly, due to the philosophical nature of customer orientation (Saxe and Weitz, 1982) we expect it to drive the behavioural aspects of employees' service orientation behaviours (c.f., theory of reasoned action, whereby attitudinal constructs drive behavioural ones, Ajzen and Fishbein, 1980).

Secondly, customer orientation has previously been linked to positive ratings of employee performance (Boles et al., 2001). We argue that employee performance ratings are similar to customers' perceptions of employee performance during service encounters, and therefore expect customer orientation to relate to service encounter quality (c.f., Brown et al., 2002).

Finally, earlier research demonstrates a positive relationship between customer orientation and customer satisfaction (Hennig-Thurau, 2004) and customer orientation and service quality (Brady and Cronin, 2001). However, the relationship between customer orientation and customer satisfaction should be mediated by service quality (Brady and Cronin, 2001; Cronin et al., 2000). Brady and Cronin (2001) tested this mediated relationship and found it to hold. However, their model does not include measures of service encounter quality or service orientation. Therefore, we expect customer orientation to have a direct influence on service quality and an indirect influence on customer satisfaction, via service quality (c.f., Brady and Cronin, 2001). We hypothesise:

$H_{7}$ : Employees' customer orientation is positively related to: a) employees' service orientation; $b$ ) customers ' perceptions of service encounter quality; and c) customers' perceptions of service quality.

\section{Service Orientation}

Service orientation has been approached from two differing perspectives: the organisational level and the individual level (Homburg et al., 2002). At an organisational level, service orientation is a strategic business philosophy (Lytle et al., 1998), focusing on what management considers important for high 
quality service delivery (Chung and Schneider, 2002). At an individual level, service orientation relates to the behaviours of employees performing service roles (Gwinner et al., 2005). More specifically, individual service orientation behaviours are those an employee considers important for high quality service delivery (Chung and Schneider, 2002).

In the current study, we investigate service orientation behaviours at the individual level since these, more than an organisational philosophy, are what will be evaluated by customers in a retail setting. We therefore adopt an individualistic definition of service orientation as the behaviours performed by employees that affect the quality of the service delivered to retail customers (Cran, 1994).

Employee service orientation is argued to have a positive influence upon the quality of service delivery (Yoon et al., 2007). Previous work has linked service orientation to courtesy from and competence of employees (Schneider and Bowen, 1985), customers' overall quality perceptions (Schneider et al., 1980), customers behavioural intentions (Beatson et al., 2008), and overall business performance (Yoon et al., 2007). We expect service orientation behaviours to be positively related to customers' service encounter quality perceptions and service quality perceptions. This is because service oriented employees are more inclined to perform service enhancing behaviours during encounters with customers (Saura et al., 2005). A higher incidence of service orientation behaviours should lead to customers' perceptions of individual service encounter quality and overall service quality being increased (c.f., Schneider et al., 1980). We hypothesise:

\section{$H_{8}$ : Employees' service orientation is positively related to customers' perceptions of a) service encounter quality; and b) service quality.}

$<$ Please Take in Figure 1 about here>

\section{METHODOLOGY}


Data was collected in the city of Gwalior, located in Madhya Pradesh, a province in the Northern part of Central India. Gwalior has a population of approximately 1.2 million. Questionnaire respondents were selected through random interception of supermarket shoppers in the city. A trained researcher intercepted every seventh person who had completed their supermarket shopping. After explaining the study rationale, respondents were given a questionnaire, and asked to self-complete based on their most recent supermarket shopping service encounter. Through this process 312 questionnaires were collected. After accounting for missing data, we had 271 usable responses. Respondents were mainly female $(51.0 \%)$ and under the age of $40(57.9 \%)$. Table 1 presents respondent characteristics.

< Take in Table 1 about Here>

\section{Measures}

Employees' customer orientation was measured using 12 items from the customer orientation section of the Selling Orientation-Customer Orientation (SOCO) scale (Saxe and Weitz, 1982). To measure employees' service orientation behaviours we adapted the 5-item scale of Gwinner et al. (2005). To measure service value we used three indicators adapted from Sweeney et al. (1999) and Sirohi et al. (1998). To measure service encounter quality we used the 8-item measure of Jayawardhena et al. (2007). To capture service quality, we used a 10-item subset of the 22-item SERVQUAL measure (c.f. Brady et al., 2005). To capture customer satisfaction we adapted five items from Brady et al. (2005) and Cronin et al. (2000). Customers' behavioural intentions were measured using four items adapted from Zeithaml et al. (1996).

The questionnaire was prepared in English as the trained researcher (a native of India) indicated that English comprehension in Gwalior was good. A nine-point Likert-type response format (strongly disagree to strongly agree) was used for all indicators. Brady et al. (2005) suggest this maximises respondent specificity compared to other response formats. See Appendix A for item measures. 
Once data was collected, we assessed measurement scale dimensionality, reliability, and validity using LISREL 8.7 with the covariance matrix as input. We performed a confirmatory factor analysis (CFA) and calculated composite reliability and average variance extracted (AVE) for each scale (see Table 2). The CFA results were acceptable $\left(\chi^{2} / \mathrm{df}=1.82 ; \mathrm{NFI}=0.981 ; \mathrm{CFI}=0.993\right.$; RMSEA $=0.055$, c.f. Hair et al., 2006). Factor loadings ranged from 0.68 to 0.82 . Composite reliability scores were greater than 0.82 . Convergent validity was indicated by AVEs greater than 0.50 (minimum 0.64 ).

$<$ Take in Table 2 about here>

To test the discriminant validity of each scale, we analysed each possible pair of constructs by comparing their fit in terms of a unidimensional model and a two-factor model (Anderson and Gerbing, 1988). All scales passed this test, indicating discriminant validity (Anderson and Gerbing, 1988). Finally, the correlations between constructs were in the a-priori expected directions, supporting the nomological validity of the constructs used in the study (Hair et al., 2006).

<Take in Table 3 about here>

$<$ Take in Figure 2 about here>

\section{Results}

Our results are shown in Figure 2 and Table 3. We find that that all but one of the hypotheses gained support. Specifically, $\mathrm{H} 1$ and $\mathrm{H} 3$ were supported as customers' perceptions of service quality were positively related to customers' perceptions of value and customer satisfaction. Similarly, customer satisfaction was positively related to customers' behavioural intentions, lending support to $\mathrm{H} 4$. Support was found for H5 and H6, in that customers' perceptions of service encounter quality were positively related to customers' perceptions of service quality and customer satisfaction. Customer orientation was positively related to service orientation, customers' perceptions of service encounter quality and customers' perceptions of service quality, supporting H7a, H7b and H7c. Service 
orientation was positively related to customers' perceptions of service encounter quality and customers' perceptions of service quality, lending support to H8a and H8b. The only unsupported hypothesis was $\mathrm{H} 2$ as perceived value was not significantly related to customer satisfaction $(t$-value $=$ 1.29).

\section{DISCUSSION}

Our study had two objectives. First, we sought to understand the role that individual retail employees play in customers' retail service evaluation and, second, we set out to investigate whether conceptual models developed primarily in the western world are transferable to India. Importantly, the Indian retail market is the fifth largest retail destination globally, and is receiving increasing research attention (Kaul et al., 2010). Overall, our results generally confirm earlier work by Brady et al. (2005) and Cronin et al. (2000).

Our major finding is that both customer orientation and service orientation of retail employees have an influence upon customers' service evaluation, supporting earlier work (e.g. Beatson et al., 2008; Saura et al., 2005; Susskind et al., 2003. This highlights the importance of both constructs, and we recommend both feature in recruitment, selection and training programs for retail employees and managers (Cran, 1994; Gwinner et al., 2005). This should result in hiring staff who are more likely to "buy-in" to the importance of the two orientations (c.f. Saxe and Weitz, 1982). It appears that how a retail organisation manages its internal practices (i.e. communicating the importance of customer and service orientation) has implications for the treatment of its customers (Cran, 1994; Schneider and Bowen, 1985), as the behaviours of individual employees have effects on customers' service evaluation.

Our findings also demonstrate how important service encounter quality is for retail organisations, as it is linked to both service quality perceptions and customer satisfaction. Academically, this augments earlier research (Jayawardhena et al., 2007). Practically, it indicates that every individual service encounter, and thus every individual retail employee, is responsible for high quality service, which in 
turn influences customers' loyalty behaviours. Retail managers cannot rely upon subgroups of employees performing well and attempting to provide an overall, store-wide, level of service. Rather, managers need to highlight the importance of service and customer orientation to all retail employees, and the role of the individual employee in service provision is clear. Again, this could be communicated in training or employee incentive programs. Our results therefore demonstrate that the creation and maintenance of high levels of service consistency is a task for each individual employee of an organisation.

Customers' perceptions of service quality were found to influence customers' perceptions of value. However, the service quality-value relationship may diminish in usefulness when it is considered that our later findings indicate that value has no significant relationship with customer satisfaction. Rather, our findings call into question the place that value has within service evaluation models investigated in an Indian context. Indeed, our model appears to replicate earlier models of service evaluation and the service quality-satisfaction-behavioural intentions framework. This finding is in direct contrast to the arguments put forward by Cronin et al. (1997) regarding the importance of researching the concept of value. Further investigation of the construct of value is warranted, particularly in the context of individualism as it was here.

Service quality's positive association with customer satisfaction was very much expected. This seems to be one of the caveats of services marketing, and given that customers' satisfaction also influenced behavioural intentions, this goes some way towards establishing the service quality-satisfactionbehavioural intentions relationship as an empirical generalisation, and adds to the global applicability of service evaluation models. For managers, it appears that prediction of customers' loyalty behaviours in non-Western contexts tends to follow a similar pattern to that of Westernised areas. It appears that customers perceiving high quality service and satisfaction indicate positive behavioural intentions, irrespective of country or culture. This could have implications for international marketing strategy, as similar strategies could be implemented across borders. 
Perhaps of most interest is our result concerning perceived value and its lack of association with customer satisfaction. Previous work found this relationship to be significant across a range of industries (Cronin et al., 1997; Cronin et al., 2000) and countries (Brady et al., 2005). It may be that in some aspects of service evaluation, India's different culture has a role to play and this lack of a significant result simply stresses the need for further examination of the value-satisfaction relationship in non-Western contexts (e.g. China or Pakistan). For managers, our findings indicate that value is not a major concern for Indian customers when determining satisfaction with a retail experience. The purchasing culture of India might offer insight. Perhaps in Indian bargaining is more common so the effect of value on satisfaction is complicated by satisfaction with the bargain. However, irrespective of value's role in an Indian context, this particular result reinforces the earlier discussion points that quality and satisfaction perceptions are of great importance, and individual employees must ensure that individual retail encounters are of high quality. Although individual assessments of service might differ across countries (i.e. in terms of the role of value), the role of individual retail employees in providing high quality service and driving customer loyalty is more stable. So, whether or not value is important, retail managers need to ensure that individual employees are both customer and service oriented, in order that they are able to deliver the best possible service during individual service encounters (c.f. Knight et al., 2007).

\section{Limitations and Future Research}

We now consider limitations and potential improvements to our study. First, we examined supermarket shoppers, limiting the generalisability of our findings beyond the retail context. It would have been useful to consider potential moderators that could influence retail service evaluation models, such as cultural differences (c.f., Hofstede, 1980). Second, we measured all constructs with a cross-sectional survey. While attempts were made to mitigate the common method variance problem through our survey design, its impact can only be conclusively ruled out if had data been collected from different sources or via longitudinal methods. Additionally, interpretation of relationships between variables, especially to inferences of causality, should be done with caution. Third, further work is necessary before current retail service evaluation models can be said to be globally applicable, 
and we urge future work to seek consider culturally different retail markets. In addition, a greater range of employee behaviours could have been examined as possible antecedents (e.g., organizational citizenship behaviours). Finally, our ultimate construct was behavioural intentions, which may or may not accurately model customers' actual behaviours.

\section{REFERENCES}

Ajzen, I. and Fishbein, M. (1980), Understanding Attitudes and Predicting Social Behavior, PrenticeHall, Englewood Cliffs, NJ.

Anderson, E.W. and Fornell, C. (1994), “A Customer Satisfaction Research Prospectus”, in Rust, R.T. and Oliver, R.L. (Eds), Service Quality: New Directions in Theory and Practice, Sage, Thousand Oaks, CA, pp. 241-68.

Anderson, J.C. and Gerbing, D.W. (1988), "Structural Equation Modeling in Practice: A Review and Recommended Two-Step Approach", Psychological Bulletin, Vol. 103, No. 3, pp. 411-23.

Andreassen, T.W. and Lindestad, B. (1998), "Customer Loyalty and Complex Services: The Impact of Corporate Image on Quality, Customer Satisfaction, and Loyalty for Customers with Varying Degrees of Service Expertise", International Journal of Service Industry Management, Vol. 9 No. 1, pp. 7-23.

Bagozzi, R.P. (1992), “The Self Regulation of Attitudes, Intentions, and Behavior”, Social Psychology Quarterly, Vol. 55, pp. 178-204.

Beatson, A., Lings, I. and Gudergan, S. (2008), "Employee Behavior and Relationship Quality: Impact on Customers", Service Industries Journal, Vol. 28, No. 2, pp. 211-23.

Bitner, M.J. (1990), "Evaluating Service Encounters: The Effects of Physical Surroundings and Employee Responses", Journal of Marketing Research, Vol. 54, No. 2, pp. 69-82.

Boles, J.S., Babin, B.J., Brashear, T.G. and Brooks, C. (2001), “An Examination of the Relationships between Retail Work Environments, Salesperson Selling Orientation-Customer Orientation and Job Performance", Journal of Marketing Theory and Practice, Vol. 9, No. 3, pp. 1-13.

Bolton, R.N. and Drew, J.H. (1991), “A Longitudinal Analysis of the Impact of Service Changes on Customer Attitudes", Journal of Marketing, Vol. 55, No. 1, pp. 1-9.

Brady, M.K. and Cronin, J.J. (2001), "Customer Orientation: Effects on Customer Service Perceptions and Outcome Behaviors", Journal of Service Research, Vol. 3, No. 3, pp. 241-51. 
Brady, M.K., Knight, G.A., Cronin, J.J., Hult, G.T.M. and Keillor, B.D. (2005), "Removing the Contextual Lens: A Multinational, Multi-Setting Comparison of Service Evaluation Models", Journal of Retailing, Vol. 81, No. 3, pp. 215-30.

Brown, T.J., Mowen, J.C., Donavan, D.T. and Licata, J.W. (2002), “The Customer Orientation of Service Workers: Personality Trait Effects on Self- and Supervisor Performance Ratings", Journal of Marketing Research, Vol. 29, No. 1, pp. 110-19.

Chung, B.G. and Schneider, B. (2002), "Serving Multiple Masters: Role Conflict Experienced by Service Employees", Journal of Services Marketing, Vol. 16, No. 1, pp. 70-87.

Cran, D.J. (1994) “Towards Validation of the Service Orientation Construct”, Service Industries Journal, Vol. 14, No. 1, pp. 34-44.

Cronin, J.J. and Taylor, S.A. (1992), "Measuring Service Quality: A Re-Examination and Extension", Journal of Marketing, Vol. 56, No. 3, pp. 55-68.

Cronin, J.J., Brady, M.K. and Hult, G.T.M. (2000), “Assessing the Effects of Quality, Value, and Customer Satisfaction on Consumer Behavioral Intentions in Service Environments", Journal of Retailing, Vol. 76, No. 2, pp. 193-218.

Cronin, J.J., Brady, M.K., Brand, R.R., Hightower, R. and Shemwell, D.J. (1997), “A Cross-Sectional Test of the Effect and Conceptualization of Service Value", Journal of Services Marketing, Vol. 11, No. 6, pp. 375-91.

Czepiel, J.A., Solomon, M.R., Surprenant, C.F. and Gutman, E.G. (1985), "Service Encounters: An Overview," in Czepiel, J.A., Solomon, M.R. and Surprenant, C.F. (Eds), The Service Encounter: Managing Employee/Customer Interaction in Service Businesses, Lexington Books, Lexington, MA, pp. 3-16.

Dholakia, R.R. and Zhao, M. (2010), "Effects of Online Store Attributes on Customer Satisfaction and Repurchase Intentions", International Journal of Retail \& Distribution Management, Vol. 38, No. 7, pp. 482-96.

Donavan, D.T., Brown, T.J. and Mowen, J.C. (2004), “Internal Benefits of Service-Worker Customer Orientation: Job Satisfaction, Commitment, and Organizational Citizenship Behaviors”, Journal of Marketing, Vol. 68, No. 1, pp. 128-46.

Eggert, A. and Ulaga, W. (2002), "Customer Perceived Value: A Substitute for Satisfaction in Business Markets”, Journal of Business \& Industrial Marketing, Vol. 17, No. 2/3, pp. 107-18.

Farrell, A.M., Souchon, A.L. and Durden, G.R. (2001), "Service Encounter Conceptualisation: Employees' Service Behaviours and Customers' Service Quality Perceptions", Journal of Marketing Management, Vol. 17, No. 5/6, pp. 577-93. 
Fornell, C., Johnson, M.D., Anderson, E.W., Cha, J. and Bryant, B.E. (1996), “The American Customer Satisfaction Index: Nature, Purpose, and Findings", Journal of Marketing, Vol. 60, No.4, pp. 7-18.

Fournier, S. and Mick, D.G. (1999), “Rediscovering Satisfaction”, Journal of Marketing, Vol. 63, No. 4, pp. 5-23.

Gupta, S. and Zeithaml, V.A. (2006), "Customer Metrics and Their Impact on Financial Performance", Marketing Science, Vol. 25, No. 6, pp. 718-39.

Gwinner, K.P., Bitner, M.J., Brown, S.W. and Kumar, A. (2005), "Service Customization through Employee Adaptiveness", Journal of Service Research, Vol. 8, No. 2, pp. 131-48.

Hair, J.F., Black, W.C., Babin, B.J., Anderson, R.A. and Tatham, R.L. (2006), Multivariate Data Analysis ( $6^{\text {th }}$ Edition), Prentice-Hall, Upper Saddle River, NJ.

Hallowell, R. (1996), “The Relationship of Customer Satisfaction, Customer Loyalty, and Profitability: An Empirical Study”, International Journal of Service Industry Management, Vol. 7, No. 4, pp. 27-42.

Hellier, P.K., Geursen, G.M., Carr, R.A. and Rickard, J.A. (2003), “Customer Repurchase Intention: A General Structural Equation Model”, European Journal of Marketing, Vol. 37, No. 11/12, pp. 1762-1800.

Hennig-Thurau, T. (2004), "Customer-Orientation of Service Employees: Its Impact on Customer Satisfaction, Commitment, and Retention", International Journal of Service Industry Management, Vol. 15, No. 5, pp. 460-78.

Hofstede, G. (1980), Cultures Consequences: International Differences in Work-Related Values, Sage, Newbury Park, CA.

Homburg, C., Hoyer, W.D. and Fassnacht, M. (2002), "Service Orientation of a Retailer's Business Strategy: Dimensions, Antecedents, and Performance Outcomes”, Journal of Marketing, Vol. 66, No. 4, pp. 86-101.

Jayawardhena, C., Souchon, A.L., Farrell, A.M. and Glanville, K. (2007), “Outcomes of Service Encounter Quality in a Business-to-Business Context”, Industrial Marketing Management, Vol. 36, No. 5, pp. 575-88.

Kaul, S., Sahay, A. and Koshy, A. (2010), “A Study of Young, Male Apparel Shoppers in India”, International Journal of Retail \& Distribution Management, Vol. 38, No. 4, pp. 275-96.

Knight, D.K., Kim, H.-J. and Crutsinger, C. (2007), "Examining the Effects of Role Stress on Customer Orientation and Job Performance of Retail Salespeople", International Journal of Retail \& Distribution Management, Vol. 35, No. 5, pp. 381-92. 
Lazarus, R.S. (1991), "Progress on a Cognitive-Motivational-Relational Theory of Emotion", American Psychologist, Vol. 46, No. 8, pp. 819-34.

Lemmink, J. and Mattsson, J. (2002), "Employee Behaviour, Feelings of Warmth and Customer Perception in Service Encounters", International Journal of Retail \& Distribution Management, Vol. 30, No. 1, pp. 18-33.

Lytle, R.S., Hom, P.W. and Mokwa, M.P. (1998), "SERV*OR: A Managerial Measure of Organizational Service-Orientation”, Journal of Retailing, Vol. 74, No. 4, pp. 455-89.

Maxham, J.G., Netemeyer, R.G. and Lichtenstein, D.R. (2008), “The Retail Value Chain: Linking Employee Perceptions to Employee Performance, Customer Evaluations, and Store Performance", Marketing Science, Vol. 27, No. 2, pp. 147-67.

Oliver, R.L. (1997), Satisfaction: A Behavioural Perspective on the Consumer, McGraw-Hill, New York.

Parasuraman, A., Zeithaml, V.A. and Berry, L.L. (1988), "SERVQUAL: A Multiple-Item Scale for Measuring Consumer Perceptions of Service Quality”, Journal of Retailing, Vol. 64, No. 1, pp. $12-40$.

Rust, R.T. and Oliver, R.L. (1994), Service Quality: New Directions in Theory and Practice, Sage Publications, Thousand Oaks, CA.

Saura, I.G., Contrí, G.B., Taulet, A.C. and Velázquez, B.M. (2005), "Relationships among Customer Orientation, Service Orientation and Job Satisfaction in Financial Services", International Journal of Service Industry Management, Vol. 16, No. 5, pp. 497-525.

Saxe, R. and Weitz, B.A. (1982), "The SOCO Scale: A Measure of the Customer Orientation of Salespeople", Journal of Marketing Research, Vol. 19, No. 3, pp. 343-51.

Schneider, B. and Bowen, D.E. (1985), "Employee and Customer Perceptions of Service in Banks: Replication and Extension”, Journal of Applied Psychology, Vol. 70, No. 3, pp. 423-33.

Schneider, B., Parkington, J.J. and Buxton, V.M. (1980), "Employee and Customer Perceptions of Service in Banks", Administrative Science Quarterly, Vol. 25, No. 2, pp. 252-67.

Shostack, G.L. (1985), "Planning the Service Encounter," in Czepiel, J.A., Solomon, M.R. and Surprenant, C.F. (Eds), The Service Encounter: Managing Employee/Customer Interaction in Service Businesses, Lexington Books, Lexington, MA, pp. 243-54.

Sirohi, N., McLaughlin, E.W. and Wittink, D.R. (1998), “A Model of Consumer Perceptions and Store Loyalty Intentions for a Supermarket Retailer”, Journal of Retailing, Vol. 74, No. 2, pp. 223-45.

Surprenant, C.F. and Solomon, M.R. (1987), "Predictability and Personalization in the Service Encounter", Journal of Marketing, Vol. 51, No. 2, pp. 86-96. 
Susskind, A.M., Kacmar, K.M. and Borchgrevink, C.P. (2003), “Customer Service Providers' Attitudes Relating to Customer Service and Customer Satisfaction in the Customer-Server Exchange", Journal of Applied Psychology, Vol. 88, No. 1, pp. 179-87.

Sweeney, J.C., Soutar, G.N. and Johnson, L.W. (1999), "The Role of Perceived Risk in the QualityValue Relationship: A Study in a Retail Environment”, Journal of Retailing, Vol. 75, No. 1, pp. $77-105$.

Yoon, S.-J., Choi, D.-C. and Park, J.-W. (2007), "Service Orientation: Its Impact on Business Performance in the Medical Service Industry”, Service Industries Journal, Vol. 27, No. 4, pp. $371-88$.

Zeithaml, V.A., Berry, L.L. and Parasuraman, A. (1996), "The Behavioral Consequences of Service Quality", Journal of Marketing, Vol. 60, No. 2, pp. 31-46. 


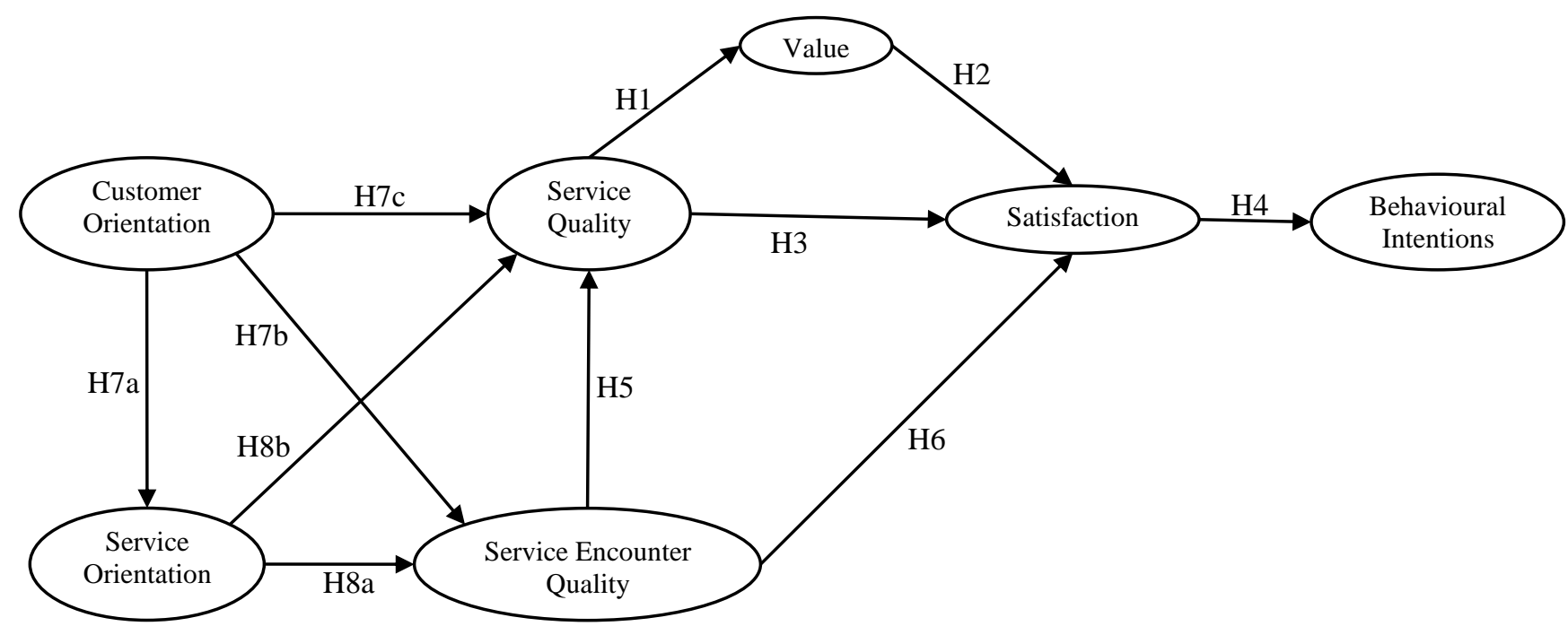

Figure 1: The Influence of Customer Orientation and Service Orientation on Retail Service Evaluation

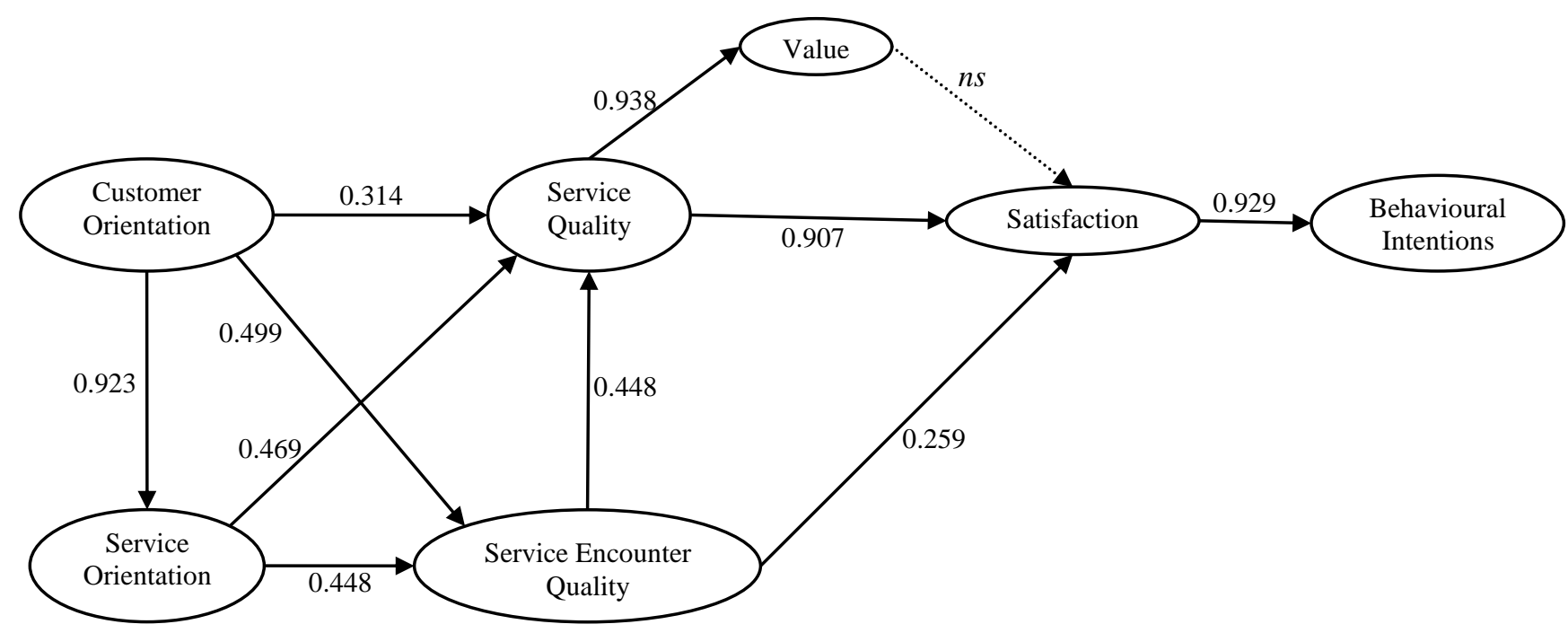

Figure 2: Structural Model Results. 


\begin{tabular}{|c|c|c|c|c|c|}
\hline \multicolumn{6}{|c|}{ Gender } \\
\hline Male & 133 & $49.00 \%$ & Female & 138 & $51.00 \%$ \\
\hline Age & $\mathrm{N}$ & $\%$ & Monthly Income (US\$) & $\mathrm{N}$ & $\%$ \\
\hline Under 21 & 28 & $10.30 \%$ & Less than $\$ 370.00$ & 55 & $20.30 \%$ \\
\hline 21 to 30 & 63 & $23.30 \%$ & $\$ 371.00$ to $\$ 616.00$ & 91 & $33.58 \%$ \\
\hline 31 to 40 & 66 & $24.30 \%$ & $\$ 617.00$ to $\$ 1232.00$ & 93 & $34.32 \%$ \\
\hline 41 to 50 & 71 & $26.00 \%$ & Over $\$ 1233.00$ & 32 & $11.81 \%$ \\
\hline Over 51 & 43 & $16.00 \%$ & & & \\
\hline
\end{tabular}

Table 1: Demographic Characteristics of Respondents 


\begin{tabular}{|c|c|c|c|}
\hline$n$ & 271 & NFI & 0.981 \\
\hline$\chi^{2}$ & 1317.30 & CFI & 0.993 \\
\hline df & 722 & RMSEA & 0.055 \\
\hline Customer Orientation (CO 8 items) & & Service Orientation (SO 5 items) & \\
\hline Composite Reliability & 0.88 & Composite Reliability & 0.87 \\
\hline Average Variance Extracted (AVE) & 0.80 & Average Variance Extracted (AVE) & 0.74 \\
\hline Parameter Estimates Range & $0.68-0.75$ & Parameter Estimates Range & $0.75-0.79$ \\
\hline Service Quality (SQ 8 items) & & Value (VAL 3 items) & \\
\hline Composite Reliability & 0.91 & Composite Reliability & 0.82 \\
\hline Average Variance Extracted (AVE) & 0.82 & Average Variance Extracted (AVE) & 0.64 \\
\hline Parameter Estimates Range & $0.73-0.76$ & Parameter Estimates Range & $0.77-0.79$ \\
\hline Satisfaction (SAT 5 items) & & Service Encounter Quality (SEQ 7 items) & \\
\hline Composite Reliability & 0.86 & Composite Reliability & 0.91 \\
\hline Average Variance Extracted (AVE) & 0.73 & Average Variance Extracted (AVE) & 0.80 \\
\hline \multirow[t]{5}{*}{ Parameter Estimates Range } & $0.72-0.75$ & Parameter Estimates Range & $0.74-0.78$ \\
\hline & & Behavioural Intentions (BI 4 items) & \\
\hline & & Composite Reliability & 0.86 \\
\hline & & Average Variance Extracted (AVE) & 0.71 \\
\hline & & Parameter Estimates Range & $0.75-0.82$ \\
\hline
\end{tabular}

Table 2: Confirmatory Factor Analysis Results 


\begin{tabular}{|c|c|c|c|c|c|c|c|c|}
\hline \multicolumn{4}{|c|}{ Path } & \multirow{2}{*}{$\begin{array}{c}\text { Coefficient } \\
0.938\end{array}$} & \multirow{2}{*}{$\frac{t \text {-value }}{12.80}$} & \multicolumn{2}{|c|}{$\mathbf{R}^{2}$} & \multirow[t]{2}{*}{ Fit Indices } \\
\hline $\mathrm{H} 1$ & SQ & $\rightarrow$ & VAL & & & $\mathrm{SO}$ & 0.88 & \\
\hline $\mathrm{H} 2$ & VAL & $\rightarrow$ & SAT & -0.149 & $1.29 *$ & SEQ & 0.86 & $\chi^{2}=1224.114$ \\
\hline $\mathrm{H} 3$ & SQ & $\rightarrow$ & SAT & 0.907 & 5.32 & SQ & 0.97 & $\mathrm{df}=735$ \\
\hline $\mathrm{H} 4$ & SAT & $\rightarrow$ & $\mathrm{BI}$ & 0.929 & 13.59 & VAL & 0.85 & $\mathrm{CFI}=0.993$ \\
\hline H5 & SEQ & $\rightarrow$ & SQ & 0.448 & 2.21 & SAT & 0.89 & $\mathrm{NFI}=0.983$ \\
\hline H6 & SEQ & $\rightarrow$ & SAT & 0.259 & 2.70 & $\mathrm{BI}$ & 0.78 & $\mathrm{NNFI}=0.993$ \\
\hline $\mathrm{H} 7 \mathrm{a}$ & $\mathrm{CO}$ & $\rightarrow$ & SO & 0.923 & 14.08 & & & RMSEA $=0.0414$ \\
\hline $\mathrm{H} 7 \mathrm{~b}$ & $\mathrm{CO}$ & $\rightarrow$ & SEQ & 0.499 & 3.46 & & & \\
\hline $\mathrm{H} 7 \mathrm{c}$ & $\mathrm{CO}$ & $\rightarrow$ & SQ & 0.314 & 2.82 & & & \\
\hline $\mathrm{H} 8 \mathrm{a}$ & SO & $\rightarrow$ & SEQ & 0.448 & 3.08 & & & \\
\hline $\mathrm{H} 8 \mathrm{~b}$ & SO & $\rightarrow$ & SQ & 0.469 & 4.04 & & & \\
\hline
\end{tabular}

* path not significant at $\mathrm{p}<0.01$; all other paths significant at $\mathrm{p}<0.01$

Note: CO: Customer Orientation; SO: Service Orientation; SQ: Perceived Service Quality; SEQ: Perceived Service Encounter Quality; VAL: Perceived Value; SAT: Customer Satisfaction; BI: Behavioural Intentions.

Table 3: Path Estimates and Fit Indices for Structural Model

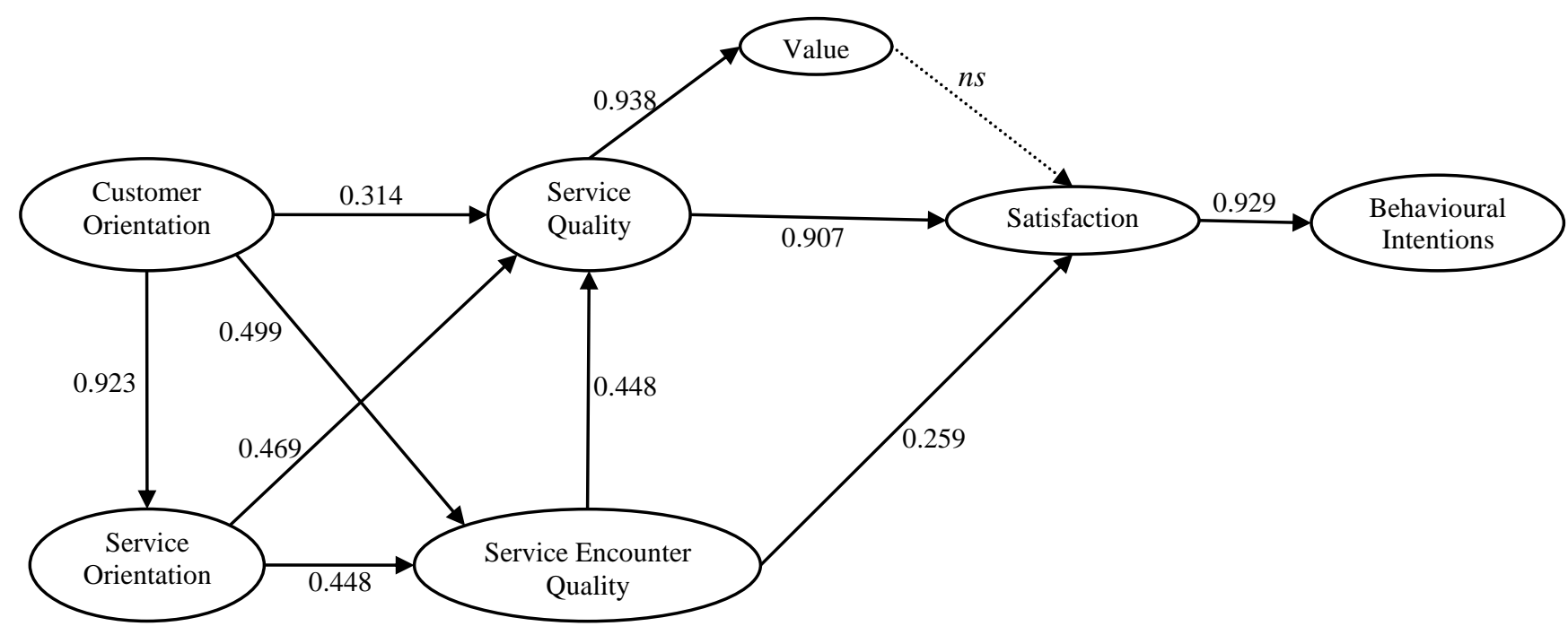




\section{Appendix A - Questionnaire Items}

\section{Customer Orientation $(\mathrm{CO})$}

1. Their employee tried to help me achieve my goals by satisfying me

2. Their employee had my best interests in mind

3. Their employee asked me to discuss my needs with them

4. Their employee influenced me with information rather than by pressure

5. Their employee tried to find out what kind of service would be most helpful to me

6. Their employee tried to bring me together with a solution that helped me

7. Their employee was willing to disagree with me in order to help me make a better decision

8. Their employee gave me an accurate expectation of what their services will do for me

9. Their employee tried to figure out what my needs were [*]

10. Their employee tried to help me achieve my goals [*]

11. I was offered the service that was best suited to the my needs [*]

12. Their employee answered my questions as correctly as possible [*]

Service Orientation (SO)

1. Their employee enjoyed helping me

2. Their employee enjoyed assisting me with solving my problems

3. I got along well with the employee

4. Their employee provided courteous service

5. Their employee was considerate of my needs

Service Quality (SQ)

1. Their employees offer the personal attention I need from them

2. The behaviour of employees instils confidence in me

3. Their employees are courteous

4. I receive enough individual attention from their employees

5. I can depend on receiving prompt service from their employees

6. I feel safe conducting business with their employees

7. Their employees are able to answer my questions

8. Their employees are never too busy to respond to my requests

9. Their employees have my best interests at heart [*]

10. Their employees understand my specific needs [*]

Service Encounter Quality (SEQ)

2. Their employee communicated coherently

3. Their employee was courteous

4. Their employee provided an informative interaction with me

5. Their employee showed familiarity to me during our encounter

6. Their employee tried to build a friendly relationship with me

7. Their employee was not pushy

8. Their employee focused on not being condescending when communicating with me

9. Their employee possessed the necessary qualifications to provide the service [*]

Value (VAL)

1. Their products are excellent value

2. At this organisation, I get a great deal for my money

3. What I get from this organisation, and its cost, makes it great value 


\title{
Satisfaction (SAT)
}

1. I am satisfied with the service I receive from this organisation

2. I am happy with the service I receive from this organisation

3. I am delighted with the service I receive from this organisation

4. This organisation's services meets my expectations

5. I think I did the right thing when I chose the service from this organisation

Behavioural Intentions (BI)

1. I would classify myself as a loyal customer of this organisation

2. If asked, I would say good things about this organisation

3. I would recommend this organisation to a friend

4. My usage of this organisation has been high

All items were measured on nine-point scales anchored by $1=$ strongly disagree to $9=$ strongly agree An item marked with [*] was deleted during the measurement purification process

\begin{abstract}
About the authors
Chanaka Jayawardhena is Senior Lecturer in Marketing at Loughborough University Business School, UK. His research examines services marketing and customer relationships. He has won numerous research awards including two Best Paper Awards at the Academy of Marketing Conference. Previous publications have appeared in the Industrial Marketing Management, European Journal of Marketing, Journal of Marketing Management, Journal of General Management, Electronic Markets, Journal of Internet Research, European Business Review, among others.
\end{abstract}

Andrew M. Farrell has done his PhD and is a lecturer in Marketing at Aston Business School, UK. His research examines services marketing, leadership, and research methodology. His works have been published in Journal of Business Research and Industrial Marketing Management and other leading business journals. 